\title{
Serum inflammatory biomarkers and clinical outcomes of COPD exacerbation caused by different pathogens
}

This article was published in the following Dove Press journal:

International Journal of COPD

31 May 2017

Number of times this article has been viewed

Theerasuk Kawamatawong'

Apitch Apiwattanaporn ${ }^{2}$

Warisara Siricharoonwong ${ }^{2}$

'Division of Pulmonary and Critical

Care Medicine, ${ }^{2}$ Department of

Medicine, Faculty of Medicine

Ramathibodi Hospital, Mahidol

University, Bangkok, Thailand
Correspondence: Theerasuk

Kawamatawong

Division of Pulmonary and Critical Care

Medicine, Department of Medicine,

Faculty of Medicine Ramathibodi Hospital,

Mahidol University, Rama 6 Road,

Rajthevi, Bangkok 10400, Thailand

Tel $+662201 \quad 1619$

Fax +6622011629

Email ktheerasuk@hotmail.com
Background and objective: COPD exacerbation is characterized by worsening of symptoms, warranting change in treatment. Systemic and airway inflammation play roles in the pathogenesis of COPD exacerbation. We hypothesized whether increased serum inflammatory biomarkers are associated with the clinical outcomes of COPD exacerbation caused by different infectious pathogens.

Methods: COPD patients with exacerbation were recruited from a hospital emergency department during 2014-2015. Serum procalcitonin (PCT) and C-reactive protein (CRP) were measured. Dyspnea, eosinopenia, consolidation, acidemia, and atrial fibrillation (DECAF) score was calculated for predicting mortality. Multiplex polymerase chain reaction was carried out for respiratory viral assay from nasopharyngeal swabs, and sputum bacterial culture was also performed. Hospital mortality, invasive mechanical ventilation requirement, and length of hospital stay (LOS) were evaluated, and their associations with clinical characteristics, DECAF score, and serum biomarkers were examined.

Results: A total of 62 COPD patients were enrolled. These patients were classified as Global Initiative for Obstructive Lung Disease (GOLD) stage 2, 3, and 4 in $12.9 \%, 6.4 \%$, and 80.7\% of cases, respectively. Isolated bacterial exacerbation was recovered in $30.6 \%$ of exacerbation episodes: Klebsiella pneumoniae was the most commonly identified bacteria. Viral pathogens and coinfections were noted in $9.6 \%$ and $16.1 \%$ of exacerbated patients, respectively. Influenza was the most commonly detected viral pathogen. Serum biomarkers and DECAF score for viruses, bacteria, coinfection, and noninfectious causes of exacerbations were similar. Neither DECAF score nor serum biomarkers were able to differentiate patients with and without mortality or requiring mechanical ventilation. Increased serum PCT was noted in patients with $L O S \geq 7$ days when compared with those with $\operatorname{LOS}<7$ days $(0.38 \mathrm{ng} / \mathrm{mL}$ vs $0.1 \mathrm{ng} / \mathrm{mL} ; P=0.035)$.

Conclusion: Increased serum PCT is associated with longer LOS in COPD exacerbation. However, CRP and DECAF score play limited roles in predicting clinical outcome and lack an association with causes of exacerbation.

Keywords: biomarkers, inflammation, viruses, bacteria, COPD exacerbation, outcome

\section{Introduction}

COPD is the fourth leading cause of death worldwide, a public health challenge that is preventable and treatable. ${ }^{1}$ Exacerbation episodes are a hallmark of this disease. COPD exacerbation is characterized by a change in the patient's baseline dyspnea, cough, and/or sputum beyond day-to-day variability sufficient to lead to a change in medication. Exacerbation is associated with not only disease progression but also increased mortality. ${ }^{2}$ Infectious causes (bacteria, viruses, and atypical pathogens) 
and non-infectious causes (environmental exposure and poor compliance with medications) have been described. . $^{3,4}$ Antibiotics have been shown to reduce mortality and treatment failure. ${ }^{5}$ Therefore, COPD guidelines of the Global Initiative for Obstructive Lung Disease (GOLD) recommend antibiotics for the treatment of exacerbations in the presence of purulent sputum. ${ }^{1,6,7}$ However, clinical findings and laboratory investigations cannot distinguish viral from bacterial exacerbation or pneumonia. ${ }^{4,8}$ Over-utilization of antibiotics in the absence of bacterial infection can cause serious drug resistance problems, while under-treatment is related to poor outcomes. The dyspnea, eosinopenia, consolidation, acidemia, and atrial fibrillation (DECAF) score was developed and further validated for predicting mortality in COPD exacerbation. ${ }^{9}$ DECAF aids clinicians in accurate prognosis, allows triage of patients to an appropriate level of care, and improves clinical outcomes. ${ }^{10}$

Apart from the clinical score, inflammatory biomarkers such as procalcitonin (PCT) and C-reactive protein (CRP) are promising tools for differentiating bacterial from nonbacterial respiratory infection in adults and children. ${ }^{11}$ PCT has shown potential for predicting outcome in lower respiratory tract infections and minimizing unnecessary antibiotic use. ${ }^{12-16}$ Increased PCT was reported in patients hospitalized with COPD exacerbation or pneumonia with proven bacterial infection. ${ }^{17}$ In addition, CRP and copeptin have been evaluated for identifying causes and predicting exacerbation outcomes. ${ }^{18}$ However, the roles of biomarkers for differentiating viral infections from bacterial infections causing COPD exacerbation are limited. We hypothesized whether increased serum inflammatory biomarkers are able to discriminate bacterial infection from viral or noninfectious causes of COPD exacerbation in an emergency room setting.

\section{Methods}

A cross-sectional study was conducted at Ramathibodi Hospital, Mahidol University, Thailand, between August 2014 and December 2015. Patients with COPD exacerbation at the emergency department were enrolled. All patients provided written, informed consent prior to participation in the study. COPD was diagnosed according to GOLD criteria with the presence of symptoms, history of risk factor exposure, and irreversible airflow limitation (postbronchodilator forced expiratory volume in 1 second/forced vital capacity $\left[\mathrm{FEV}_{1} / \mathrm{FVC}\right]$ less than 0.7$) .{ }^{1}$ Risk stratification was performed according to Anthonisen criteria: increased degree of dyspnea, increased sputum volume, and presence of sputum purulence. ${ }^{6}$
All patients underwent investigations to identify infectious causative pathogens. Nasopharyngeal swabs were taken for detecting different strains of respiratory viruses by analyzing $18 \mathrm{~S}$ ribosomal RNA. This viral detection method used an $\mathrm{xTAG}^{\circledR}$ RVP Fast v2 assay (Luminex Cooperation, Austin, TX, USA) for multiplex reverse transcription-polymerase chain reactions (RT-PCRs). Bacterial lower respiratory tract infections were determined by aerobic bacterial culture of expectorated sputum using a fluorescent technology system (Bactec ${ }^{\mathrm{TM}}$; Becton Dickinson, Franklin Lakes, NJ, USA). PCT and CRP were measured simultaneously at the emergency department within $48 \mathrm{~h}$ after the diagnosis of COPD exacerbation: serum PCT by electrochemiluminescence immunoassay on a Cobas e601 analyzer (Roche, Switzerland) and serum CRP on a Cobas c501 system. Arterial blood samples were obtained. Chest radiography was performed for detecting pulmonary opacity, and the results were reported by an experienced radiologist. Complete blood count was performed after whole blood assay. Total eosinophil count was obtained with hemocytometer. Electrocardiography was performed using standard leads, and any signs of cardiac arrhythmia were reported. Functional status was classified using a modified Medical Research Council dyspnea scale. The previously mentioned parameters were integrated to obtain the DECAF score. Clinical outcomes were reviewed in all patients, including hospital mortality, invasive mechanical ventilation requirement, and total length of hospital stay (LOS). The study was approved by Ethics Committee of Human Study, Ramathibodi Hospital, Mahidol University.

\section{Statistical analysis}

Continuous data were expressed as mean and standard deviation (SD) or median as appropriate. Comparisons of continuous variables between two and more independent groups were made by $t$-test and analysis of variance or nonparametric statistics (Mann-Whitney test and Kruskal-Wallis test) according to the distribution. The association between two categorical variables was examined using chi-square or Fisher's exact test. Statistical analysis was performed using PASW Statistics 18; a $P$-value of $<0.05$ was considered to be statistically significant.

\section{Results}

A total of 62 COPD patients were enrolled. According to GOLD guideline, these patients were classified as stage 2, 3 , and $4(12.9 \%, 6.4 \%$, and $80.7 \%$, respectively). The demographics, baseline pharmacologic treatments, and clinical findings of exacerbated COPD are shown in Table 1. 
Table I Clinical characteristics of COPD exacerbation during emergency room visit $(n=62)$

\begin{tabular}{ll}
\hline Characteristics & Mean \pm SD or \\
& $\mathbf{n}(\%)$ \\
\hline Mean age (years) & $79.16 \pm 5.0$ \\
Male gender & $55(88.7 \%)$ \\
Post-bronchodilator FEV 1 (\% predicted) & $37.01 \pm 12.5$ \\
White blood cell count at ER (cells/mm $\left.{ }^{3}\right)$ & $12,675 \pm 5,732$ \\
$\mathrm{P}_{\mathrm{a}} \mathrm{CO}_{2}$ at ER (mmHg) & $43.3 \pm 13.7$ \\
Number of underlying medical diseases & $2.8($ range $0-8)$ \\
Patients with ICS/LABA or ICS treatment & $52(83.8 \%)$ \\
Patients with influenza vaccination in the past year & $2(3.2 \%)$ \\
\hline
\end{tabular}

Abbreviations: SD, standard deviation; $\mathrm{FEV}_{1}$, forced expiratory volume in I second; $E R$, emergency room; $\mathrm{P}_{\mathrm{a}} \mathrm{CO}_{2}$, partial pressure of arterial carbon dioxide; ICS, inhaled corticosteroid; LABA, long acting $\beta 2$ agonist.

Influenza was the most commonly detected virus ( 9 of 16 cases, 56.25\%) from PCR. Klebsiella pneumoniae was the most commonly isolated pathogenic bacteria from sputum culture. The identified bacterial and viral pathogens are summarized in Table 2.

The prevalence rates of isolated viral exacerbation, isolated bacterial exacerbations, and coinfection of viruses and bacteria in COPD patients were 9.6\%, 30.6\%, and $16.1 \%$, respectively. Hence, $43.6 \%$ of exacerbated patients were classified as noninfectious etiology. The clinical characteristics

Table 2 Bacterial pathogens obtained using sputum aerobic bacterial culture and viral pathogens obtained using multiplex reverse transcription-polymerase chain reaction (RT-PCR)

\begin{tabular}{|c|c|c|c|}
\hline Bacterial pathogen & $\begin{array}{l}\text { Number of } \\
\text { samples* }\end{array}$ & Viral pathogen & $\begin{array}{l}\text { Number of } \\
\text { samples* }\end{array}$ \\
\hline \multicolumn{4}{|c|}{ Gram-negative bacteria } \\
\hline Klebsiella pneumoniae & 9 & Influenza $A / B$ & 9 \\
\hline Pseudomonas aeruginosa & 5 & Rhinovirus & 4 \\
\hline Escherichia coli & 4 & Coronavirus & 2 \\
\hline Haemophilus influenzae & 3 & $\begin{array}{l}\text { Human } \\
\text { metapneumovirus }\end{array}$ & 2 \\
\hline Acinetobacter baumannii & 3 & Enterovirus & I \\
\hline $\begin{array}{l}\text { Stenotrophomonas } \\
\text { maltophilia }\end{array}$ & 2 & Parainfluenza & 1 \\
\hline Proteus mirabilis & $\mathrm{I}$ & $\begin{array}{l}\text { Respiratory } \\
\text { syncytial virus }\end{array}$ & 1 \\
\hline Neisseria spp. & I & & \\
\hline \multicolumn{4}{|c|}{ Gram-positive bacteria } \\
\hline Streptococcus viridans & 16 & & \\
\hline Staphylococcus aureus & 4 & & \\
\hline Coagulase-negative & 5 & & \\
\hline \multicolumn{4}{|l|}{ Staphylococci } \\
\hline Enterobacter cloacae & 3 & & \\
\hline Corynebacterium spp. & 3 & & \\
\hline Group D Streptococci & 2 & & \\
\hline Enterococcus spp. & 1 & & \\
\hline
\end{tabular}

Note: *More than one pathogen was identified in exacerbated patient respiratory samples. including DECAF score and serum biomarker are summarized in Table 3.

There was no difference in terms of invasive mechanical ventilation $(P=0.137), \operatorname{LOS}>7$ days $(P=0.302)$, and hospital death $(P=0.151)$ among exacerbated patients with isolated viral infection, isolated bacterial infection, coinfection, or noninfectious group. However, culture-proven bacterial lower respiratory tract infection was noted in 19 of 25 hospitalizations. Hence, bacterial infection was associated with hospitalization $(P=0.007)$. The higher median serum PCT in exacerbated patients with positive sputum bacterial culture was $0.22 \mathrm{ng} / \mathrm{mL}(0.04-19.29)$ compared to those with negative bacterial culture $0.11 \mathrm{ng} / \mathrm{mL}(0.03-18.48)$. However, the difference did not reach statistical significance. Regarding exacerbation outcomes, serum biomarkers and DECAF score were similar for COPD-exacerbated patients who survived versus those who died and who were intubated versus those who were not. The results are shown in Table 4.

The increased PCT was noted in COPD-exacerbated patients with LOS $\geq 7$ days when compared with LOS $<7$ days $(0.38 \mathrm{ng} / \mathrm{mL}$ vs $0.1 \mathrm{ng} / \mathrm{mL}, P=0.035)$. Results are shown in Table 5. In terms of clinical characteristics and laboratory investigations, low serum albumin $(<30 \mathrm{~g} / \mathrm{L})$ was associated with longer hospitalization for COPD exacerbation $(P=0.028)$. In addition, the higher serum PCT $(\geq 0.25 \mathrm{ng} / \mathrm{mL})$ was associated with the longer LOS $\geq 7$ days when compared with PCT $<0.25 \mathrm{ng} / \mathrm{mL}(P=0.015)$. Most of exacerbated patients who were treated without invasive mechanical ventilator had LOS $<7$ days. Hence, invasive ventilation was associated with $\operatorname{LOS} \geq 7$ days $(P<0.004)$.

\section{Discussion}

The prevalence of viral exacerbation ranged from $25 \%$ to $48 \%$ according to the detection methods in several previous reports. ${ }^{419,20}$ Adenovirus was the most commonly identified respiratory virus causing exacerbation in a study by Sethi and Murphy. ${ }^{4}$ A systematic review has shown conflicting results for viral etiologies identified using PCR. ${ }^{3}$ However, influenza was the most prevalent virus in this study, since coverage by influenza vaccination in our cohort was very low. Streptococcus pneumoniae, Haemophilus influenzae, and Moraxella catarrhalis are common bacterial causes of exacerbation. ${ }^{8}$ Enteric gram-negative bacteria are more common in severe COPD in Thailand. In this study, K. pneumoniae was a common bacterial pathogen. This is similar to a previous Asian multicenter study which included Thailand. ${ }^{21}$ Our study included COPD with severe airflow limitation, which may increase lower airway bacterial colonization..$^{22}$ Coinfection 
Table 3 Clinical characteristics including DECAF score and serum inflammatory biomarkers of COPD patients with exacerbation according to etiologies

\begin{tabular}{|c|c|c|c|c|c|}
\hline Clinical features & $\begin{array}{l}\text { Virus } \\
n=6 \\
(9.6 \%)\end{array}$ & $\begin{array}{l}\text { Bacteria } \\
n=19 \\
(30.6 \%)\end{array}$ & $\begin{array}{l}\text { Coinfection } \\
n=10 \\
(16.1 \%)\end{array}$ & $\begin{array}{l}\text { Noninfectious } \\
n=27 \\
(43.6)\end{array}$ & $P$-value \\
\hline Mean age (years)* & $81.30(6.9)$ & $79.00(7.9)$ & $79.90(4.8)$ & $77.95(7.5)$ & 0.73 \\
\hline Comorbid $\geq 2$ disease, $n$ (\%) & $3(50.0 \%)$ & $9(47.3 \%)$ & $5(50.0 \%)$ & $6(22.2 \%)$ & 0.60 \\
\hline ICS + LABA or ICS, n (\%) & $5(83.3 \%)$ & $16(84.2 \%)$ & $10(100 \%)$ & $22(81.4 \%)$ & 0.58 \\
\hline LAMA, n (\%) & $3(50.0 \%)$ & $10(52.6 \%)$ & $5(50 \%)$ & $14(5 \mid .8 \%)$ & 0.39 \\
\hline Oral long acting xanthine, $\mathrm{n}(\%)$ & $4(66.7 \%)$ & $9(47.3 \%)$ & $2(20 \%)$ & I5 (55\%) & 0.66 \\
\hline $\mathrm{P}_{\mathrm{a}} \mathrm{CO}_{2}$ at ER $(\mathrm{mmHg})^{\#}$ & $34.2(9.0)$ & $41.1(15.9)$ & $45.7(9.9)$ & $47.3(15.1)$ & 0.24 \\
\hline Serum albumin $(g / L)^{\#}$ & $29.1(8.8)$ & $30.9(8.0)$ & $25.0(11.2)$ & $28.3(6.7)$ & 0.38 \\
\hline WBC count $\left(\text { cells } / \mathrm{mm}^{3}\right)^{*}$ & $\begin{array}{l}11,930 \\
(7,920-14,210)\end{array}$ & $\begin{array}{l}15,950 \\
(6,500-40,480)\end{array}$ & $\begin{array}{l}11,725 \\
(6,950-22,240)\end{array}$ & $\begin{array}{l}|0,33| \\
(5,099-20,000)\end{array}$ & 0.25 \\
\hline Eosinophil count (cells $\left./ \mathrm{mm}^{3}\right)^{*}$ & $82(0-399)$ & $216(0-1,584)$ & $326(0-1,024)$ & II $(0-1,60 \mathrm{I})$ & 0.76 \\
\hline DECAF* & $2.5(2-5)$ & $3.0(2-5)$ & $2.0(I-4)$ & $2.0(I-4)$ & 0.46 \\
\hline PCT $(\mathrm{ng} / \mathrm{mL})^{*}$ & $\begin{array}{l}0.26 \\
(0.07-18.48)\end{array}$ & $\begin{array}{l}0.30 \\
(0.04-17.6)\end{array}$ & $\begin{array}{l}0.31 \\
(0.05-1.63)\end{array}$ & $\begin{array}{l}0.09 \\
(0.03-19.29)\end{array}$ & 0.35 \\
\hline $\mathrm{CRP}(\mathrm{mg} / \mathrm{L})^{*}$ & $\begin{array}{l}37.46 \\
(23.69-700.0)\end{array}$ & $\begin{array}{l}41.62 \\
(4.16-274.8)\end{array}$ & $\begin{array}{l}34.24 \\
(9.03-67.56)\end{array}$ & $\begin{array}{l}15.56 \\
(1.0-238.5)\end{array}$ & 0.45 \\
\hline
\end{tabular}

Notes: "Data were presented as mean (SD) and *data were presented as median (range).

Abbreviations: DECAF, dyspnea, eosinopenia, consolidation, acidemia, and atrial fibrillation; ICS, inhaled corticosteroid; LABA, long acting $\beta 2$ agonist; LAMA, long acting muscarinic antagonist; $\mathrm{P}_{\mathrm{a}} \mathrm{CO}_{2}$, partial pressure of arterial carbon dioxide; ER, emergency room; WBC, white blood cells; PCT, procalcitonin; CRP, C-reactive protein; $\mathrm{SD}$, standard deviation.

with bacteria and viruses in COPD exacerbation was not uncommon in our cohort similar to a previous report. ${ }^{19}$ Initial viral infection followed by subsequent bacterial infection is associated with mechanical ventilation requirement and longer hospitalization. ${ }^{19,23}$ However, there was no difference in clinical outcomes between coinfection and isolated infection in terms of mortality in our study.

COPD exacerbation is characterized by increased inflammatory mediators and airway inflammation. ${ }^{19}$ Increased biomarker levels are related to disease severity. ${ }^{24}$ For example, PCT level is associated with exacerbation severity, LOS, and hospital mortality. ${ }^{17,25,26}$ Elevated serum CRP in COPD

Table 4 Comparison of serum biomarkers and DECAF score of exacerbated patients: survived versus dead patients and nonintubated versus intubated patients

\begin{tabular}{llll}
\hline Parameter & $\begin{array}{l}\text { Survived } \\
\text { patients }(\mathbf{n}=\mathbf{6 0})\end{array}$ & $\begin{array}{l}\text { Patients who } \\
\text { died }(\mathbf{n}=\mathbf{2})\end{array}$ & P-value \\
\hline PCT $(\mathrm{ng} / \mathrm{mL})$ & $0.1 \mathrm{I}(0.03-19.29)$ & $\mathrm{I} .175(0.47-\mathrm{I} .88)$ & $0.12 \mathrm{I}$ \\
$\mathrm{CRP}(\mathrm{mg} / \mathrm{L})$ & $25.37(\mathrm{I}-700)$ & $76.53(67-85)$ & 0.233 \\
DECAF score & $2(\mathrm{I}-5)$ & $2(2-2)$ & $0.40 \mathrm{I}$ \\
\hline Parameter & Non-intubated & Intubated & P-value \\
& patients $(\mathbf{n}=\mathbf{5 7})$ & patients $(\mathbf{n}=\mathbf{5})$ & \\
\hline PCT $(\mathrm{ng} / \mathrm{mL})$ & $0.1 \mathrm{I}(0.03-19.29)$ & $0.38(0.06-0.47)$ & 0.373 \\
CRP $(\mathrm{mg} / \mathrm{L})$ & $26.79(\mathrm{I}-700)$ & $37.46(10-67)$ & 0.867 \\
DECAF score & $2(\mathrm{I}-5)$ & $2(2-4)$ & 0.822 \\
\hline
\end{tabular}

Note: Data were presented as median (range).

Abbreviations: DECAF, dyspnea, eosinopenia, consolidation, acidemia, and atrial fibrillation; PCT, procalcitonin; CRP, C-reactive protein. exacerbation has also been reported; ${ }^{27}$ however, it was not correlated with LOS or disease severity. ${ }^{26}$ Similarly, in our study, increased serum PCT, but not CRP, was associated with longer LOS ( $\geq 7$ days). Although the DECAF score is used for evaluating exacerbation severity and predicting mortality, this score could not differentiate between patients with and without poor outcome mortality and invasive ventilation requirement in our study. ${ }^{10}$ Because lower numbers

Table 5 Comparison of clinical presentation and biomarkers of exacerbated patients with LOS $<7$ days and $\geq 7$ days

\begin{tabular}{|c|c|c|c|}
\hline Parameter & $\begin{array}{l}\text { LOS }<7 \text { days } \\
(n=42)\end{array}$ & $\begin{array}{l}\text { LOS } \geq 7 \text { days } \\
(n=20)\end{array}$ & $P$-value \\
\hline PCT $(\mathrm{ng} / \mathrm{mL})^{*}$ & $0.10(0.03-19.6)$ & $0.38(0.05-18.48)$ & 0.03 \\
\hline $\mathrm{CRP}(\mathrm{mg} / \mathrm{L})^{*}$ & $27(I-274)$ & $37(4-700)$ & 0.31 \\
\hline DECAF score* & $2(I-5)$ & $3(2-4)$ & 0.05 \\
\hline $\begin{array}{l}\text { Number of } \\
\text { comorbidities* }\end{array}$ & $3(0-5)$ & $3(1-6)$ & 0.92 \\
\hline Age (years) ${ }^{\#}$ & $78.74(8.0)$ & $80.59(6.2)$ & 0.40 \\
\hline Serum albumin $(\mathrm{mg} / \mathrm{dL})^{\#}$ & $3 I .4 I(8.1)$ & $25.2(6.8)$ & 0.01 \\
\hline $\mathrm{P}_{\mathrm{a}} \mathrm{CO}_{2}$ at $\mathrm{ER}^{\#}$ & $42.63(14.34)$ & $45.85(12.78)$ & 0.44 \\
\hline WBC count $\left(\text { cells } / \mathrm{mm}^{3}\right)^{*}$ & $\begin{array}{l}12,264 \\
(5,270-24,390)\end{array}$ & $\begin{array}{l}14,397 \\
(5,360-40,480)\end{array}$ & 0.23 \\
\hline $\begin{array}{l}\text { Invasive mechanical } \\
\text { ventilation, } \mathrm{n}(\%)\end{array}$ & $37(88.1 \%)$ & $6(30.0 \%)$ & 0.004 \\
\hline
\end{tabular}

Notes: *Data were presented as median (range) and \#data were presented as mean (SD).

Abbreviations: LOS, length of hospital stay; PCT, procalcitonin; CRP, C-reactive protein; DECAF, dyspnea, eosinopenia, consolidation, acidemia, and atrial fibrillation; $\mathrm{P}_{\mathrm{a}} \mathrm{CO}_{2}$, partial pressure of arterial carbon dioxide; ER, emergency room; WBC, white blood cells. 
of patients were enrolled in this study with few exacerbated patients reporting mortality.

Confounders that are associated with length of COPD hospitalization, such as age, severity of COPD, hypoalbuminemia, hypercapnia, leukocytosis, comorbidities, and ventilator support, must be taken into account. ${ }^{28,29}$ Our findings showed that the serum albumin $<30 \mathrm{~g} / \mathrm{L}(P=0.01)$ and invasive ventilator support $(<0.05)$ were associated with hospitalization $\geq 7$ days similar to the previous study. ${ }^{28}$ After adjusting for the effect of confounders, elevated serum PCT ( $\geq 0.25 \mathrm{ng} / \mathrm{mL}$ ) was associated with prolonged LOS in this study in accordance with a previous report. ${ }^{14}$ The use of $0.25 \mathrm{ng} / \mathrm{mL}$ of PCT is generally recommended as a cutoff level for antibiotic therapy. This biomarker approach differentiates between bacterial and viral respiratory infections and minimizes unnecessary antibiotic use. ${ }^{30}$

Serum biomarkers did not differ significantly between exacerbated patients with or without bacterial infection in our study. Despite that the finding of our study is similar to that of the previous report. ${ }^{31}$ This is possibly due to a lack of statistical power because of the small sample size enrolled. Despite that using serum PCT and CRP did not discriminate virus-associated exacerbations from others. ${ }^{32}$ However, IL-6 is a promising serum biomarker, which has been studied. Higher serum IL-6 was noted in viral than nonviral exacerbation. ${ }^{33}$ In addition, coinfection of rhinovirus and $H$. influenzae in COPD exacerbation is associated with higher serum IL-6 compared to those without both pathogens. ${ }^{34}$

Nevertheless, the results of these serum biomarkers for differentiating COPD exacerbating causes are inconclusive from previous studies and systematic review. ${ }^{35,36}$ In addition, identifying other serum biomarkers may improve the ability to predict COPD exacerbation outcome. Furthermore, integrating biomarkers into clinical findings or composite score is a promising approach. However, the role of inflammatory biomarkers in stratifying COPD exacerbation has to be further evaluated.

\section{Conclusion}

Bacterial and viral infections are the common causes of COPD exacerbation. There was no difference in mortality in exacerbated COPD for different etiologies. Serum PCT is capable of predicting longer hospital stay regardless of the etiology of exacerbation. The role of DECAF score in predicting exacerbation outcomes was limited in this study.

\section{Disclosure}

The authors report no conflicts of interest in this work.

\section{References}

1. Global Initiative for Chronic Obstructive Lung Disease (GOLD). Global strategy for the diagnosis, management, and prevention of COPD. Available from: http://goldcopd.org/. Accessed June 7, 2016.

2. Donaldson GC, Seemungal TA, Bhowmik A, Wedzicha JA. Relationship between exacerbation frequency and lung function decline in chronic obstructive pulmonary disease. Thorax. 2002;57(10): $847-852$.

3. Mohan A, Chandra S, Agarwal D, et al. Prevalence of viral infection detected by PCR and RT-PCR in patients with acute exacerbation of COPD: a systematic review. Respirology. 2010;15(3):536-542.

4. Sethi S, Murphy TF. Infection in the pathogenesis and course of chronic obstructive pulmonary disease. $N$ Engl J Med. 2008;359(22): 2355-2365.

5. Roede BM, Bresser P, Prins JM, Schellevis F, Verheij TJ, Bindels PJ. Reduced risk of next exacerbation and mortality associated with antibiotic use in COPD. Eur Respir J. 2009;33(2):282-288.

6. Anthonisen NR, Manfreda J, Warren CP, Hershfield ES, Harding GK, Nelson NA. Antibiotic therapy in exacerbations of chronic obstructive pulmonary disease. Ann Intern Med. 1987;106(2):196-204.

7. Brunton S, Carmichael BP, Colgan R, et al. Acute exacerbation of chronic bronchitis: a primary care consensus guideline. Am J Manag Care. 2004;10(10):689-696.

8. Sethi S. Infectious etiology of acute exacerbations of chronic bronchitis. Chest. 2000;117(5 Suppl 2):380S-385S.

9. Echevarria C, Steer J, Heslop-Marshall K, et al. Validation of the DECAF score to predict hospital mortality in acute exacerbations of COPD. Thorax. 2016;71(2):133-140.

10. Steer J, Gibson J, Bourke SC. The DECAF Score: predicting hospital mortality in exacerbations of chronic obstructive pulmonary disease. Thorax. 2012;67(11):970-976.

11. Assicot M, Gendrel D, Carsin H, Raymond J, Guilbaud J, Bohuon C. High serum procalcitonin concentrations in patients with sepsis and infection. Lancet. 1993;341(8844):515-518.

12. Bafadhel M, Clark TW, Reid C, et al. Procalcitonin and C-reactive protein in hospitalized adult patients with community-acquired pneumonia or exacerbation of asthma or COPD. Chest. 2011;139(6): 1410-1418.

13. Crisafulli E, Menéndez R, Huerta A, et al. Systemic inflammatory pattern of patients with community-acquired pneumonia with and without COPD. Chest. 2013;143(4):1009-1017.

14. Huerta A, Crisafulli E, Menéndez R, et al. Pneumonic and nonpneumonic exacerbations of COPD: inflammatory response and clinical characteristics. Chest. 2013;144(4):1134-1142.

15. Koutsokera A, Stolz D, Loukides S, Kostikas K. Systemic biomarkers in exacerbations of COPD: the evolving clinical challenge. Chest. 2012;141(2):396-405.

16. Briel M, Schuetz P, Mueller B, et al. Procalcitonin-guided antibiotic use vs a standard approach for acute respiratory tract infections in primary care. Arch Intern Med. 2008;168(18):2000-2007; discussion 2007-2008.

17. Daubin C, Parienti JJ, Vabret A, et al. Procalcitonin levels in acute exacerbation of COPD admitted in ICU: a prospective cohort study. BMC Infect Dis. 2008;8:145.

18. Stolz D, Christ-Crain M, Morgenthaler NG, et al. Copeptin, C-reactive protein, and procalcitonin as prognostic biomarkers in acute exacerbation of COPD. Chest. 2007;131(4):1058-1067.

19. Papi A, Bellettato CM, Braccioni F, et al. Infections and airway inflammation in chronic obstructive pulmonary disease severe exacerbations. Am J Respir Crit Care Med. 2006;173(10):1114-1121.

20. Sethi S. Molecular diagnosis of respiratory tract infection in acute exacerbations of chronic obstructive pulmonary disease. Clin Infect Dis. 2011;52(Suppl 4):S290-S295

21. Hui DS, Ip M, Ling T, et al. A multicentre surveillance study on the characteristics, bacterial aetiologies and in vitro antibiotic susceptibilities in patients with acute exacerbations of chronic bronchitis. Respirology. 2011;16(3):532-539. 
22. Sethi S, Sethi R, Eschberger K, et al. Airway bacterial concentrations and exacerbations of chronic obstructive pulmonary disease. Am J Respir Crit Care Med. 2007;176(4):356-361.

23. Cameron RJ, de Wit D, Welsh TN, Ferguson J, Grissell TV, Rye PJ. Virus infection in exacerbations of chronic obstructive pulmonary disease requiring ventilation. Intensive Care Med. 2006;32(7):1022-1029.

24. Chen H, Wang D, Bai C, Wang X. Proteomics-based biomarkers in chronic obstructive pulmonary disease. J Proteome Res. 2010;9(6): 2798-2808.

25. Rammaert B, Verdier N, Cavestri B, Nseir S. Procalcitonin as a prognostic factor in severe acute exacerbation of chronic obstructive pulmonary disease. Respirology. 2009;14(7):969-974.

26. Müller B, Harbarth S, Stolz D, et al. Diagnostic and prognostic accuracy of clinical and laboratory parameters in community-acquired pneumonia. BMC Infect Dis. 2007; 7:10.

27. Weis N, Almdal T. C-reactive protein - can it be used as a marker of infection in patients with exacerbation of chronic obstructive pulmonary disease? Eur J Intern Med. 2006;17(2):88-91.

28. Wang Y, Stavem K, Dahl FA, Humerfelt S, Haugen T. Factors associated with a prolonged length of stay after acute exacerbation of chronic obstructive pulmonary disease (AECOPD). Int J Chron Obstruct Pulmon Dis. 2014;9:99-105.

29. Agboado G, Peters J, Donkin L. Factors influencing the length of hospital stay among patients resident in Blackpool admitted with COPD: a cross-sectional study. BMJ Open. 2012;2(5):e000869.
30. Schuetz P, Christ-Crain M, Thomann R, et al; ProHOSP Study Group. Effect of procalcitonin-based guidelines vs standard guidelines on antibiotic use in lower respiratory tract infections: the ProHOSP randomized controlled trial. JAMA. 2009;302(10):1059-1066.

31. Schuetz P, Albrich W, Mueller B. Procalcitonin for diagnosis of infection and guide to antibiotic decisions: past, present and future. $B M C$ Med. 2011;9:107.

32. Kherad O, Kaiser L, Bridevaux PO, et al. Upper viral respiratory infection, biomarkers and COPD exacerbations. Chest. 2010;138(4):896-904.

33. Seemungal T, Harper-Owen R, Bhowmik A, et al. Respiratory viruses,symptoms, and inflammatory markers in acute exacerbations and stable chronic obstructive pulmonary disease. Am J Respir Crit Care Med. 2001;164(9):1618-1623.

34. Wilkinson TM, Hurst JR, Perera WR, Wilks M, Donaldson GC, Wedzicha JA. Effect of interactions between lower airway bacterial and rhinoviral infection in exacerbations of COPD. Chest. 2006;129(2): 317-324.

35. Lacoma A, Prat C, Andreo F, et al. Value of procalcitonin, C-reactive protein, and neopterin in exacerbations of chronic obstructive pulmonary disease. Int J Chron Obstruct Pulmon Dis. 2011;6:157-169.

36. Chen YW, Leung JM, Sin DD. A systematic review of diagnostic biomarkers of COPD exacerbation. PLoS One. 2016;11(7):e0158843.
International Journal of COPD

\section{Publish your work in this journal}

The International Journal of COPD is an international, peer-reviewed journal of therapeutics and pharmacology focusing on concise rapid reporting of clinical studies and reviews in COPD. Special focus is given to the pathophysiological processes underlying the disease, intervention programs, patient focused education, and self management protocols.

\section{Dovepress}

This journal is indexed on PubMed Central, MedLine and CAS. The manuscript management system is completely online and includes a very quick and fair peer-review system, which is all easy to use. Visit http://www.dovepress.com/testimonials.php to read real quotes from published authors. 